\title{
The Lectin-Like Domain of Thrombomodulin Inhibits $\beta 1$ Integrin-Dependent Binding of Human Breast Cancer-Derived Cell Lines to Fibronectin
}

\author{
Eiji Kawamoto ${ }^{1,2, *(\mathbb{D})}$, Nodoka Nago ${ }^{3}$, Takayuki Okamoto ${ }^{4} \mathbb{D}$, Arong Gaowa ${ }^{1}$, Asami Masui-Ito ${ }^{1,2}$, \\ Yuichi Akama 1,2 , Samuel Darkwah ${ }^{1}$, Michael Gyasi Appiah ${ }^{1}$, Phyoe Kyawe Myint ${ }^{1}$ (D), Gideon Obeng ${ }^{1}$, \\ Atsushi Ito ${ }^{1} \mathbb{D}$, Siqingaowa Caidengbate ${ }^{1}$, Ryo Esumi ${ }^{1,2}$, Takanori Yamaguchi ${ }^{1}$, Eun Jeong Park ${ }^{1} \mathbb{D}$, \\ Hiroshi Imai ${ }^{2}$ and Motomu Shimaoka ${ }^{1}$
}

\section{check for}

updates

Citation: Kawamoto, E.; Nago, N.; Okamoto, T.; Gaowa, A.; Masui-Ito, A.; Akama, Y.; Darkwah, S.; Appiah, M.G.; Myint, P.K.; Obeng, G.; et al. The Lectin-Like Domain of Thrombomodulin Inhibits $\beta 1$ Integrin-Dependent Binding of Human Breast Cancer-Derived Cell Lines to Fibronectin. Biomedicines 2021, 9, 162. https://doi.org/ $10.3390 /$ biomedicines 9020162

Academic Editor: Jean Amiral

Received: 25 January 2021

Accepted: 3 February 2021

Published: 7 February 2021

Publisher's Note: MDPI stays neutral with regard to jurisdictional claims in published maps and institutional affiliations.

Copyright: (c) 2021 by the authors. Licensee MDPI, Basel, Switzerland. This article is an open access article distributed under the terms and conditions of the Creative Commons Attribution (CC BY) license (https:/ / creativecommons.org/licenses/by/ $4.0 /)$.
1 Department of Molecular Pathobiology and Cell Adhesion Biology, Mie University Graduate School of Medicine, 2-174 Edobashi, Tsu-city, Mie 514-8507, Japan; arong-g@doc.medic.mie-u.ac.jp (A.G.); shironeko1am@yahoo.co.jp (A.M.-I.); y-akama@nms.ac.jp (Y.A.); kwekuadarkwah@gmail.com (S.D.); 317ds06@m.mie-u.ac.jp (M.G.A.); 317ds09@m.mie-u.ac.jp (P.K.M.);318ds16@m.mie-u.ac.jp (G.O.); i-atsushi@clin.medic.mie-u.ac.jp (A.I.); 320d011@m.mie-u.ac.jp (S.C.); ryoo1582@hotmail.co.jp (R.E.); norinori_0712@yahoo.co.jp (T.Y.); epark@doc.medic.mie-u.ac.jp (E.J.P.); motomushimaoka@gmail.com (M.S.)

2 Department of Emergency and Disaster Medicine, Mie University Graduate School of Medicine, 2-174 Edobashi, Tsu-city, Mie 514-8507, Japan; hi119@clin.medic.mie-u.ac.jp

3 Department of Clinical Nutrition, Suzuka University of Medical Science, 1001-1 Kishioka-cho, Suzuka-city, Mie 510-0293, Japan; nagou@suzuka-u.ac.jp

4 Department of Pharmacology, Faculty of Medicine, Shimane University, 89-1 Enya-cho, Izumo-city, Shimane 693-8501, Japan; okamoto@med.shimane-u.ac.jp

* Correspondence: a_2.uk@mac.com; Tel.: +81-59-232-5036; Fax: +81-59-231-5209

\begin{abstract}
Thrombomodulin is a molecule with anti-coagulant and anti-inflammatory properties. Recently, thrombomodulin was reported to be able to bind extracellular matrix proteins, such as fibronectin and collagen; however, whether thrombomodulin regulates the binding of human breast cancer-derived cell lines to the extracellular matrix remains unknown. To investigate this, we created an extracellular domain of thrombomodulin, TMD123-Fc, or domain deletion TM-Fc proteins (TM domain $12-\mathrm{Fc}_{\mathrm{C}}$ TM domain $23-\mathrm{Fc}$ ) and examined their bindings to fibronectin in vitro by ELISA. The lectin-like domain of thrombomodulin was found to be essential for the binding of the extracellular domain of thrombomodulin to fibronectin. Using a V-well cell adhesion assay or flow cytometry analysis with fluorescent beads, we found that both TMD123-Fc and TMD12-Fc inhibited the binding between $\beta 1$ integrin of human breast cancer-derived cell lines and fibronectin. Furthermore, TMD123$F_{C}$ and TMD12-Fc inhibited the binding of activated integrins to fibronectin under shear stress in the presence of $\mathrm{Ca}^{2+}$ and $\mathrm{Mg}^{2+}$ but not under strong integrin-activation conditions in the presence of $\mathrm{Mg}^{2+}$ without $\mathrm{Ca}^{2+}$. This suggests that thrombomodulin $\mathrm{Fc}_{c}$ fusion protein administered exogenously at a relatively early stage of inflammation may be applied to the development of new therapies that inhibit the binding of $\beta 1$ integrin of breast cancer cell lines to fibronectin.
\end{abstract}

Keywords: thrombomodulin; integrin; breast cancer cell; cell adhesion; V-well assay

\section{Introduction}

Thrombomodulin (TM) is considered an important cofactor of the anticoagulation protein $C$ system present in vascular endothelial cells [1]. In addition, TM can exert anti-inflammatory and cytoprotective properties and was found to be a key component regulating the binding of vascular endothelial cells to white blood cells [2]. TM is expressed in tumor cells in addition to normal vascular endothelial cells, with its expression in tumor cells suggested to regulate tumor cell invasion and proliferation in certain types of cancer. For example, in esophageal cancer, TM expression in cancer cells in metastases is reduced relative to that in primary tumors [3]. Furthermore, low TM expression in invasive breast 
cancer cells is significantly correlated with cancer recurrence rates [4]. These findings suggest that TM might play an important role in cancer growth and metastasis. A recent study showed that TM binds to the extracellular matrix (ECM), including fibronectin (FN), collagen, and laminin, of vascular endothelial cells and tumor cells [5]. However, it remains unknown whether TM regulates the binding of human breast cancer-derived cell lines to the ECM.

Integrins are composed of $\alpha$ - and $\beta$-subunit heterodimers, with $18 \alpha$ and $8 \beta$ subunits and $24 \alpha$ and $\beta$ heterodimer combinations identified [6]. Among these integrins, $\beta 1$ integrin is expressed by almost all cells and binds to ECM components, such as fibronectin, collagen, and laminin. It also connects the actin filament-like cytoskeletal system within the cell and plays an important role in cell adhesion. In particular, $\alpha 5 \beta 1$ integrin plays an important role in cell adhesion, migration, proliferation, and differentiation in both normal and tumor cells [7]. For example, the association between elevated expression levels of $\beta 1$ integrin in cancer cells and poor prognosis has been reported in tumor cells such as breast $[8,9]$ and lung cancer [10]. In a breast cancer model using $\beta 1$ conditional knockout $(\mathrm{KO})$ mice, the involvement of $\beta 1$ integrins on the surface of cancer cells has been emphasized in breast cancer development [11] and metastasis [12]. Therefore, studies on the molecular interactions between integrin $\alpha 5 \beta 1$ and its ligands might be essential to interpret the biological functions and underlying mechanisms of $\alpha 5 \beta 1$ integrin.

We hypothesized that if TM inhibits the binding of $\beta 1$ integrin from human breast cancer-derived cell lines to fibronectin in the ECM, then it might represent a new therapeutic strategy for inhibiting cancer growth and metastasis. To test this hypothesis, in this study, we generated TMD123-Fc and domain-deletion TM proteins (TMD12-Fc and TMD23-Fc) fused with an extracellular domain of TM (TMD123) and human IgG Fc fusion protein. These Fc fusion proteins contain extracellular domains expressed on the luminal side of the vessel among the TM components and might contact blood cells or tumor cells suspended in the vessel or lymph node. We analyzed these fusion proteins for their effects on the binding of $\beta 1$ integrin from human breast cancer-derived cell lines (i.e., MDA-MB-231 and MCF-7) to fibronectin. Our results will contribute to the development of new therapeutic strategies to inhibit the metastasis of breast cancer cells.

\section{Materials and Methods}

2.1. Construction of a Recombinant Human TM (Domains 1, 2, and 3)-Immunoglobulin Fc Fusion Protein (TMD123-Fc) Expression Vector

A DNA fragment containing TM domains 1,2, and 3 was amplified by PCR from the pSV2TMJ2 vector [13], which contains the entire sequence of human TM. The TMD123 sequence was subcloned into the human IgG1 Fc frame of the pcDNA3.1(+) vector at the HindIII / BamHI site [14]. Plasmids for domain deletion mutants of soluble TM-Fc fusion proteins (i.e., TM domain 23-Fc lacking domain 1, TM domain 12-Fc lacking domain 3, and Fc lacking domains 1, 2, and 3) were generated by inverse PCR using the TM domain 123-Fc-containing pcDNA3.1(+) plasmid as the template.

\subsection{Expression and Purification of TM Domain-Fc Fusion Proteins}

TM domain 123-Fc or mutant TM-Fc plasmids (TM domain 12-Fc, TM domain 23-Fc, and $\mathrm{Fc}$ ) were transiently transfected into the human embryonic kidney cell line 293T (HEK293T) cells (ATCC no. CRL-1573; ATCC, Manassas, VA, USA) using Lipofectamine 2000 reagent (Invitrogen, Tokyo, Japan). HEK293T cells were cultured in Opti-MEM (Gibco; Invitrogen, Tokyo, Japan) without fetal bovine serum (FBS) for 7 days at $37^{\circ} \mathrm{C}$, and the supernatant was collected. TM domain $123-\mathrm{Fc}$ and other mutant proteins secreted in the supernatant were purified with protein A-affinity using the Amicon Pro purification system (Millipore Japan, Tokyo, Japan). The purity of TM domain 123-Fc and mutant proteins was confirmed by SDS-PAGE [14]. 


\subsection{V-Well Cell Adhesion Assay}

A cell adhesion assay using a 96-well V-well plate was performed as previously described [15]. The V-well was coated with $100 \mu \mathrm{L}$ of $10 \mu \mathrm{g} / \mathrm{mL}$ fibronectin (SigmaAldrich, Tokyo, Japan) or control 1\% bovine serum albumin (BSA) as an integrin ligand. Plates were incubated overnight at $4{ }^{\circ} \mathrm{C}$ and blocked with phosphate-buffered saline (PBS) containing $1 \%$ BSA for $2 \mathrm{~h}$ at $37^{\circ} \mathrm{C}$. A solution of $100 \mu \mathrm{L}$ of HEPES-buffered saline (HBS) containing $1 \times 10^{4}$ calcein-labeled MDA-MB-231 $\beta 1$ integrin wild type (WT), MDAMB-231 $\beta 1$ integrin-KO cells, or MCF-7 cells in either $1 \mathrm{mM} \mathrm{Mg}{ }^{2+} / \mathrm{Ca}^{2+}$ or $2 \mathrm{mM}$ EDTA was dispensed into each well. TMD123-Fc, mutant TM-Fc fusion protein, or control human IgG1 Fc protein were dissolved in PBS and aliquoted into each well to confirm the inhibitory effect of fibronectin and $\beta 1$ integrin-mediated cell adhesion. Conversion of molar concentrations of proteins was as follows: $0.25 \mu \mathrm{M}$ TMD123-Fc to $38.8 \mu \mathrm{g} / \mathrm{mL}$, $0.25 \mu \mathrm{M}$ TMD12-FC to $37.2 \mu \mathrm{g} / \mathrm{mL}, 0.25 \mu \mathrm{M}$ TMD23-Fc to $27.1 \mu \mathrm{g} / \mathrm{mL}$, and $0.25 \mu \mathrm{M}$ Fc to $12.8 \mu \mathrm{g} / \mathrm{mL}$. Before centrifugation, V-wells with cells were incubated at $37^{\circ} \mathrm{C}$ for $5 \mathrm{~min}$. Shear stress was loaded to confirm integrin-dependent binding. To load the shear stress, the plates were centrifuged at $280 \mathrm{~g}(1200 \mathrm{rpm})$ for $5 \mathrm{~min}$ using a swing-bucket rotor (EX-125; Takaratomy Seiko Co., Ltd., Tokyo, Japan). Non-adherent cells that accumulated at the bottom of the wells were detected using the 2030 ARVO X-2 Multilabel Reader (PerkinElmer Japan, Kanagawa, Japan). We calculated the binding affinity between cells and integrin ligands, as follows:

$$
\text { Binding Affinity }(\%)=\left\{\mathrm{FL}(\mathrm{EDTA})-\mathrm{FL}\left(\mathrm{Mg}^{2+} / \mathrm{Ca}^{2+}\right)\right\} / \mathrm{FL}(\mathrm{EDTA}) \times 100
$$

where FL(EDTA) represents the fluorescence intensity of integrin binding to the integrin ligand in the presence of $2 \mathrm{mM}$ EDTA, and $\mathrm{FL}\left(\mathrm{Mg}^{2+} / \mathrm{Ca}^{2+}\right)$ represents the fluorescence intensity of integrin binding to the integrin ligand in the presence of $1 \mathrm{mM} \mathrm{Mg}^{2+} / \mathrm{Ca}^{2+}$. In the presence of $2 \mathrm{mM}$ EDTA, non-adherent cells were concentrated at the bottom of the V-well to elicit an increase in fluorescence intensity. In the presence of $1 \mathrm{mM} \mathrm{Mg}^{2+} / \mathrm{Ca}^{2+}$, integrins were activated, and cells adhered to integrin ligands attached to the V-well, resulting in decreases in fluorescence intensity. Introduction of an adhesion inhibitor, such as an integrin antibody or TM, resulted in aggregation of non-adherent cells at the bottom of the V-well and increased fluorescence intensity.

\subsection{Cell Culture}

The HEK293T, MDA-MB-231, and MCF-7 cell lines were maintained at $37^{\circ} \mathrm{C}$ in Dulbecco's modified Eagle medium supplemented with $10 \%$ FBS in a humidified atmosphere containing $5 \% \mathrm{CO}_{2}$. All cell lines were purchased from ATCC.

\section{5. $\beta 1$. Integrin KO Cell with CRISPR/CAS9 System}

The sgRNA-specified oligo sequence of human $\beta 1$ integrin exon 2 (forward; $5^{\prime}$-CACCG GAGGAATGTTACACACGGCTGC-3' ${ }^{\prime}$, reverse; 5'-AAACGCAGCCGTGTAACATTCCTCC TCCTCC-3') was cloned into the pSpCas9(BB)-2A-Puro (PX459) V2.0 (Addgene plasmid ID: 62988; Addgene, Watertown, MA, USA) vector [16]. pSpCas9(BB)-2A-Puro (PX459) V2.0 was a gift from Feng Zhang (plasmid \#62988; Addgene). This plasmid was transfected into MDAMB-231 cells using the Lipofectamine 2000 reagent (Invitrogen). After $72 \mathrm{~h}$ of transfection, the cells were selected with $10 \mu \mathrm{g} / \mathrm{mL}$ of puromycin. After 10 days of incubation, colonyforming $\beta 1$ integrin $\mathrm{KO}$ cells were picked up and incubated further in a 96-well plate and selected twice. $\beta 1$ integrin $\mathrm{KO}$ cells were identified by flow cytometric analysis.

\subsection{Enzyme-Linked Immunosorbent Assay (ELISA)}

TMD123-Fc and its domain mutant protein were immobilized in 96-well flat plates at $4{ }^{\circ} \mathrm{C}$ overnight. The immobilized protein concentration is as follows: $0.25 \mu \mathrm{M}$ TMD123-Fc to $38.8 \mu \mathrm{g} / \mathrm{mL}, 0.25 \mu \mathrm{M}$ TMD12-FC to $37.2 \mu \mathrm{g} / \mathrm{mL}, 0.25 \mu \mathrm{M}$ TMD23-Fc to $27.1 \mu \mathrm{g} / \mathrm{mL}$, and $0.25 \mu \mathrm{M}$ Fc to $12.8 \mu \mathrm{g} / \mathrm{mL}$. The next day, the wells were washed twice with PBS, $100 \mu \mathrm{L}$ of $1 \mu \mathrm{g} / \mathrm{mL}$ FN was injected into the wells, and the plate was allowed to incubate 
for $1 \mathrm{~h}$ at room temperature. The wells were then washed twice with PBS and incubated with $10 \mu \mathrm{g} / \mathrm{mL}$ of anti-human fibronectin antibody (HRP-conjugated detection antibody; cat. no. 1470-05; SouthernBiotech, Birmingham, AL, USA) for $1 \mathrm{~h}$ at $4{ }^{\circ} \mathrm{C}$. Thereafter, the wells were washed twice with PBS. For the detection of fibronectin binding to TMD123-Fc, the OD450 was measured according to the instructions of the ELISA kit (BD OptEIA; cat. no. 550534; BD Biosciences, Franklin Lakes, NJ, USA).

\subsection{Flow Cytometry Analysis}

MDA-MB-231 and MCF-7 cells were grown to 90\% confluence, detached from the culture dish using trypsin with $1 \mathrm{mM}$ EDTA, washed with FACS buffer (PBS with $2 \mathrm{mM}$ EDTA, $2 \%$ BSA, and $0.05 \%$ NaN3), and stained with the $\beta 1$ integrin primary antibody $(10 \mu \mathrm{g} / \mathrm{mL})$ for $30 \mathrm{~min}$ at room temperature. The sample was then incubated with a secondary antibody (FITC-anti-mouse IgG, $15 \mu \mathrm{g} / \mathrm{mL}$ ) for $30 \mathrm{~min}$ at room temperature. The cells were washed three times with FACS buffer and analyzed for integrin expression using a BD Accuri C6 system (BD Biosciences).

\subsection{Antibodies Targeting Integrins}

The following antibodies were used for the identification of integrins: anti-integrin $\beta 1$ monoclonal antibody (mAb; clone P5D2, MAB17781; R\&D Systems, Minneapolis, MN, USA), $\beta 1$ mAb (clone P5D2, sc-13590, lot K2618; Santa Cruz Biotechnology, Dallas, TX, USA), $\beta 3$ mAb (clone VIPL2, ab92393, lot GR274279-1; Abcam, Cambridge, UK), $\beta 6$ mAb (clone CSbwta6, NBP2-29800, lot 3120164; NOVUS, Littleton, CO, USA), $\alpha 6$ mAb (clone BQ16, sc-13542; Santa Cruz Biotechnology), and mouse IgG1 isotype control antibody (clone MOPC-21, 70-4714, lot P4714032717703; Tonbo, San Diego, CA, USA). FITC-conjugated goat anti-mouse IgG (H+L, cat. no. 115-095-003; Jackson ImmunoResearch Laboratories, West Grove, PA, USA) was used as a secondary antibody. Other antibodies included the following: anti-integrin $\alpha 1 \mathrm{mAb}-\mathrm{PE}$ (clone TS2/7, cat. no. 328304, Lot B268325; Biolegend, San Diego, CA, USA), anti-integrin $\alpha 2$ mAb-PE (clone P1E6-C5 PE, cat. no. 359308; Biolegend), anti-integrin $\alpha 3$ mAb-PE (clone ASC-1, cat. no. 343803, lot B266733; Biolegend), anti-integrin $\alpha 4$ mAb-PE (clone 9F10, cat. no. 304304, lot B288306; Biolegend), anti-integrin $\alpha 5$ mAb-PE (clone NK1-SAM-1, cat. no. 328010, lot B268740; Biolegend), anti-integrin $\alpha \mathrm{V}$ mAb-FITC (clone P2W7, cat. no. 134480, lot 100959; Lifespan Biosciences, Seattle, WA, USA), anti-integrin $\alpha 8$ mAb-PE (clone 481709, cat. no. MA5-23677, UK2877873; Invitrogen), anti-integrin $\alpha \mathrm{IIb}$ (CD41) mAb-FITC (clone H1P8, cat. no. 303704, lot B239666; Biolegend), anti-integrin $\beta 5$ mAb-PE (clone AST-3T (cat. no. 345203, lot B283165; Biolegend), integrin $\beta 7$ mAb-PE (clone FIB504, cat. no. 321204, lot B274285; Biolegend), mouse IgG1 isotype control antibody-PE (clone MOPC-21, cat. no. 400112, lot B273446; Biolegend), mouse IgG1 isotype control antibody-FITC (clone MOPC-21, cat. no. 400108, lot B258679; Biolegend), mouse IgG2b isotype control antibody-PE (clone MPC-11, cat. no. 400312, lot B285393; Biolegend), and rat IgG2a isotype control antibody-PE (clone RTK2758, cat. no. 400508, lot B316163; Biolegend).

\subsection{Cell Adhesion Experiments Using Fibronectin-Coated Fluorescent Beads}

Fluorescent beads $(20 \mu \mathrm{L} ; 3 \mu \mathrm{m}$ in diameter; cat. no. 17155; Fluoresbrite Plain Microspheres; Polysciences, Inc., Warrington, PA, USA) were mixed with $10 \mu \mathrm{g}$ fibronectin or $10 \mu \mathrm{g}$ BSA and incubated at room temperature for $15 \mathrm{~min}$. PBS $(1 \mathrm{~mL})$ was then added to the tube, and the beads were incubated at $4{ }^{\circ} \mathrm{C}$ for $12 \mathrm{~h}$. The following day, the beads were blocked with $1 \mathrm{M}$ glycine for $30 \mathrm{~min}$ at room temperature and washed twice with $1 \%$ BSA/PBS. The beads were dissolved in $100 \mu \mathrm{L}$ of $1 \%$ BSA/PBS, and $5 \mu \mathrm{L}$ was mixed with $6 \times 10^{4}$ MDA-231 cells and simultaneously mixed with either $2 \mathrm{mM}$ EDTA, $1 \mathrm{mM}$ $\mathrm{Mg}^{2+} / \mathrm{Ca}^{2+}, 1 \mathrm{mM} \mathrm{Mg}{ }^{2+}, 0.25 \mu \mathrm{M}$ TM-Fc proteins, or $10 \mu \mathrm{g} / \mathrm{mL} \beta 1$ integrin antibody and incubated on a flat shaker at $150 \mathrm{rpm}$ (cat. no. SK-O180-E; DLAB, Co., Ltd., Beijing, China) for $15 \mathrm{~min}$ at room temperature. The binding of fibronectin-coated fluorescent beads to MDA-231 was measured by flow cytometry. 


\subsection{Statistical Analysis}

Statistical analyses were performed using SPSS software (v.26.0; IBM Corp., Armonk, NY, USA). Results are presented as the mean \pm standard deviation. Wilcoxon and MannWhitney tests were used for within-group comparisons. Statistical significance was set at $p<0.05$.

\section{Result}

\subsection{The Lectin-Like Extracellular Domain of TM Binds Fibronectin}

To elucidate which of the three extracellular domains (lectin-like domain (domain 1; D1), epidermal growth factor (EGF)-like domain (domain 2; D2), and serine-threonine-rich domain (domain 3; D3)) of TM binds fibronectin, we fused the extracellular domain with human IgG Fc protein to create the TMD123-Fc protein (Figure 1). Two different concentrations $(0.25 \mu \mathrm{M}, 0.1 \mu \mathrm{M})$ of TMD123-F, TMD12-Fc, TMD23-Fc, or Fc were immobilized in the plate. Subsequently, we observed that fibronectin bound to the TM protein containing the lectin-like domain $(p<0.05)$ (Figure 2$)$, whereas TMD23-Fc did not bind fibronectin. This result suggested that the lectin-like domain of TM is required for the binding of TMD123-FC to fibronectin.

\subsection{Binding of Human Breast Cancer-Derived Cell Lines to Fibronectin Is Inhibited by TMD123-Fc in a Concentration-Dependent Manner}

Fibronectin is the major ligand for $\beta 1$ integrin [17]. A previous study demonstrated that $\alpha \operatorname{Irb} \beta 3, \alpha \mathrm{V} \beta 3, \alpha \mathrm{V} \beta 6, \alpha \mathrm{V} \beta 1, \alpha 5 \beta 1, \alpha 8 \beta 1, \alpha 4 \beta 1$, and $\alpha 4 \beta 7$ integrins bind fibronectin [18]. Among these integrins, $\alpha 5 \beta 1$ integrin is expressed on MDA-MB-231 and MCF-7 cells (Figure 3 and Supplementary Materials Figure S1). We then generated $\beta 1$ integrin-KO MDA-MB-231 cells using the CRISPR/Cas9 $\beta 1$ integrin-KO system (Figure 4). Surprisingly, the $\alpha 5$ subunit expressed on the cell surface was also lost. This suggests that the integrins must have a coordinated presence of $\alpha \beta$ subunits on the cell surface. Next, to investigate whether MDA-MB-231 was inhibited by TMD123-Fc through the binding of $\beta 1$ integrin to fibronectin, we evaluated binding of the $\beta 1$ integrin to fibronectin by adding a divalent ion $\left(1 \mathrm{mM} \mathrm{Mg}^{2+}\right.$ and $\left.\mathrm{Ca}^{2+}\right)$ to immobilized fibronectin and activating the integrin by applying shear stress to the $\beta 1$ integrin from human breast cancer-derived cell lines. We found that the binding of fibronectin to $\beta 1$ integrin was inhibited by TMD123-Fc in a concentration-dependent manner $(p<0.05)$ (Figure 5a,c).

\subsection{The Lectin-Like Domain of TM Inhibits the Binding of $\beta 1$ Integrin from Human Breast Cancer-Derived Cell Lines to Fibronectin}

Among the extracellular domains of TM, the lectin-like domain binds fibronectin (Figure 2). Therefore, we hypothesized that the binding of human breast cancer-derived cell lines to fibronectin would be inhibited by TMD123-Fc $(0.25 \mu \mathrm{M})$ and TMD12-Fc $(0.25 \mu \mathrm{M})$ but not by TMD23-Fc $(0.25 \mu \mathrm{M})$. To test this hypothesis, fibronectin $(10 \mu \mathrm{g} / \mathrm{mL})$ was immobilized in V-well plates and MDA-MB-231 or MCF-7 $\beta 1$ integrin was activated by shear stress in the presence of $1 \mathrm{mM} \mathrm{Mg}^{2+}$ and $\mathrm{Ca}^{2+}$. Only TMD123-Fc and TMD12-Fc inhibited the binding of fibronectin to integrin, indicating that only proteins with the TM lectin-like domain inhibited binding $(p<0.05)$ (Figure $5 \mathrm{~b}, \mathrm{~d}$ ). This result suggests that the lectin-like domain of TM plays an important role in inhibiting fibronectin binding to $\beta 1$ integrin. 


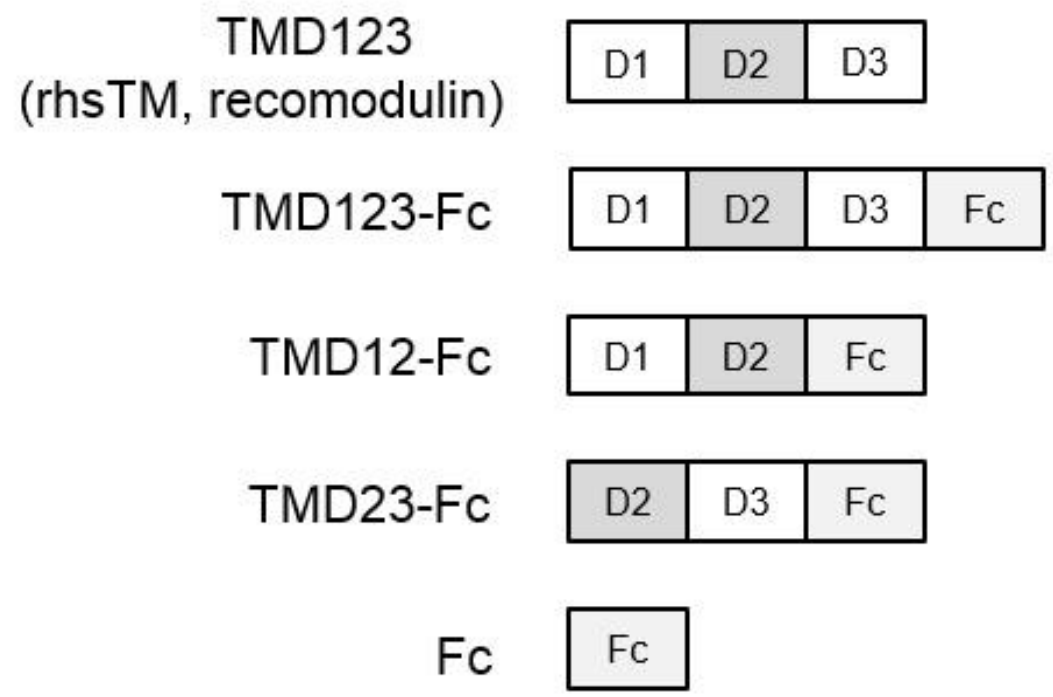

Figure 1. Illustration of extracellular domains of Thrombomodulin (TM) and domain-deleted mutant TM-Fc proteins. TMD123 is also known as rhsTM (Recomodulin), a treatment drug for septic disseminated intravascular coagulation. TM has large extracellular domains (domains 1-3): N-terminal C-type lectin-like domain (D1), the epidermal growth factor-like domain (D2), and the membrane proximal serine/threonine-rich domain (D3). Fc represents the human IgG Fc region.

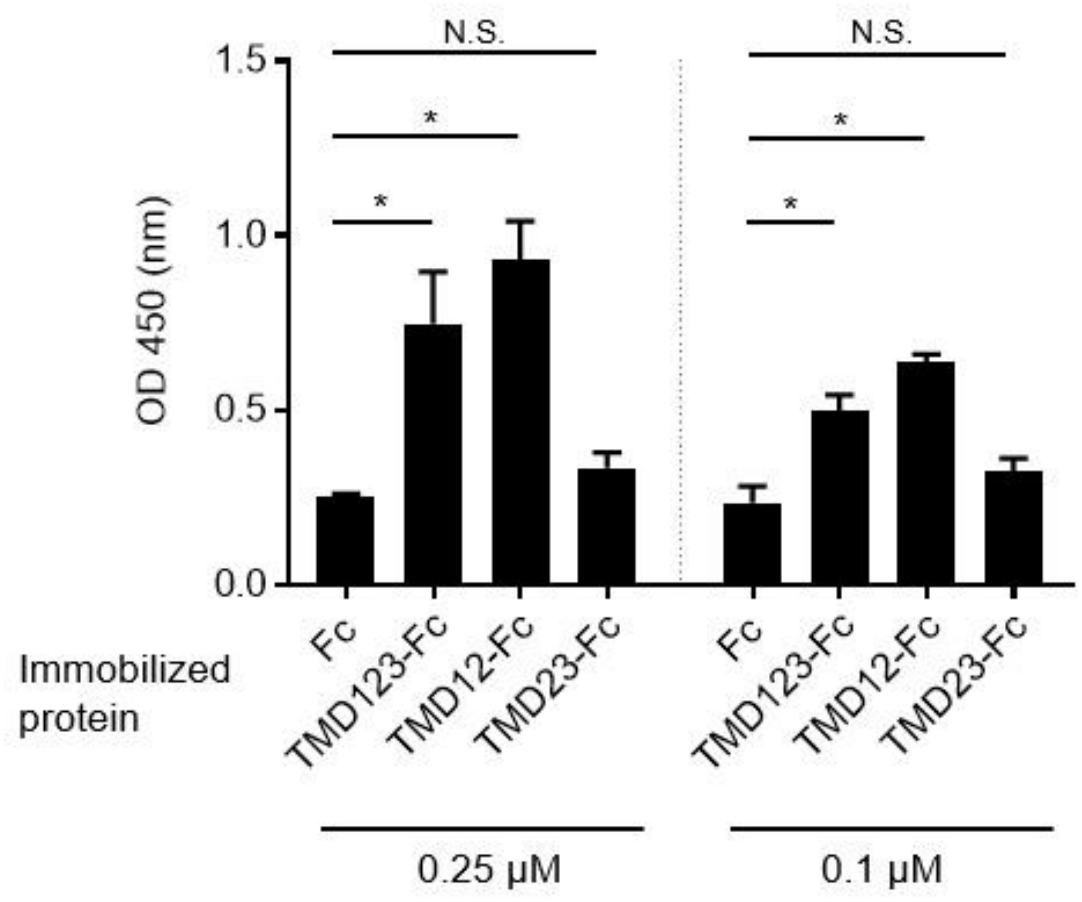

Figure 2. Adhesion of extracellular domains of TM (TM) and domain-deleted mutant TM-Fc proteins to fibronectin (FN). Two concentrations of TM-Fc were immobilized in 96-well flat plates, and after FN $(1 \mu \mathrm{g} / \mathrm{mL})$ was administered, adhesion was detected by ELISA using anti-fibronectin-HRP. Experiments were performed in triplicate and repeated three times with similar results. OD (optical density) was read at $450 \mathrm{~nm}$. Data are expressed as mean \pm SD. ${ }^{*} p<0.05$ compared with Fc. N.S.: not significant. 


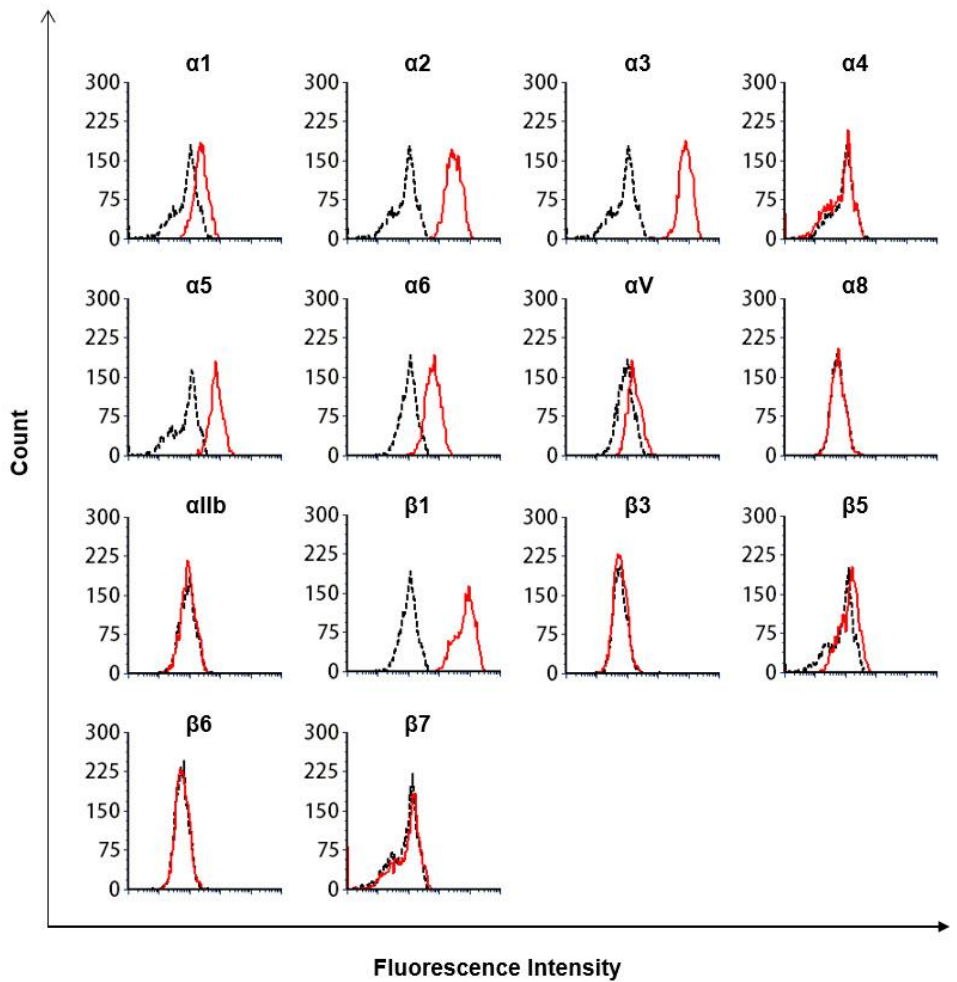

Figure 3. Flow cytometry analysis of integrin expression on MDA-MB-231 cells. Dotted lines represent isotype controls, and solid lines represent integrin expression. Results are representative of three experiments with similar results.

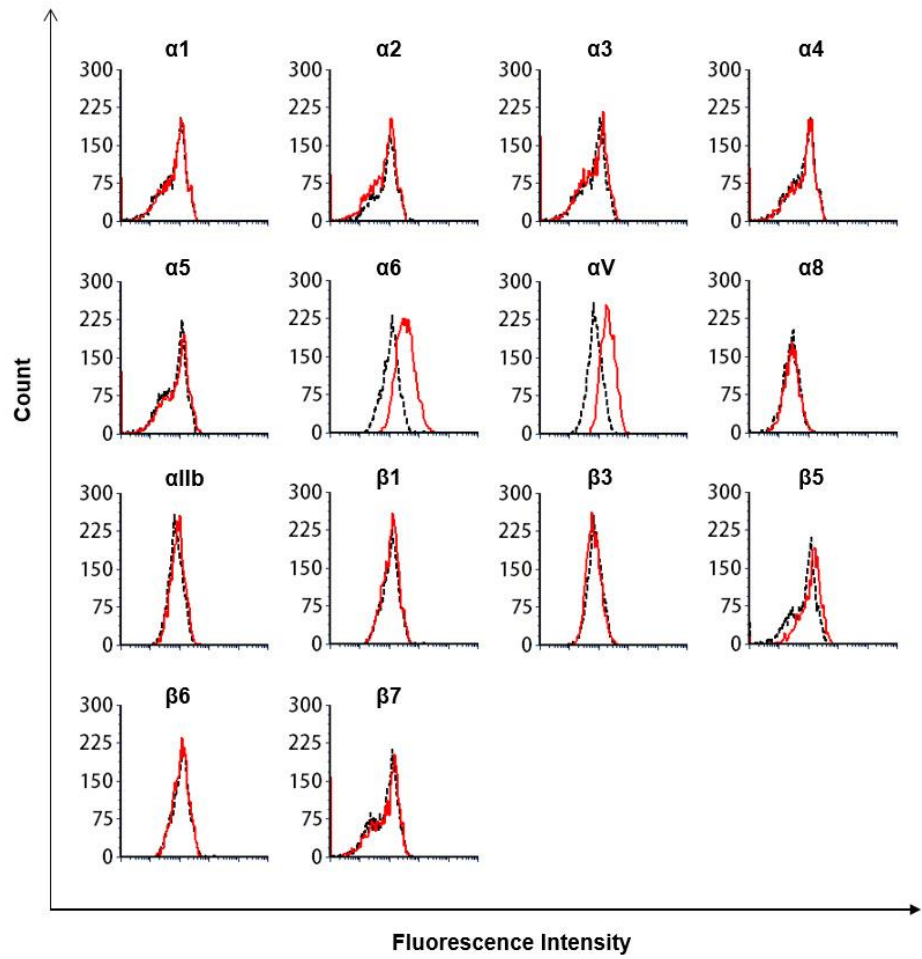

Figure 4. Flow cytometry analysis of integrin expression on MDA-MB-231 $\beta 1$ integrin-KO cells. Dotted lines represent isotype controls, and solid lines represent integrin expression. The figure is a representative of three experiments with similar results. 
(a)

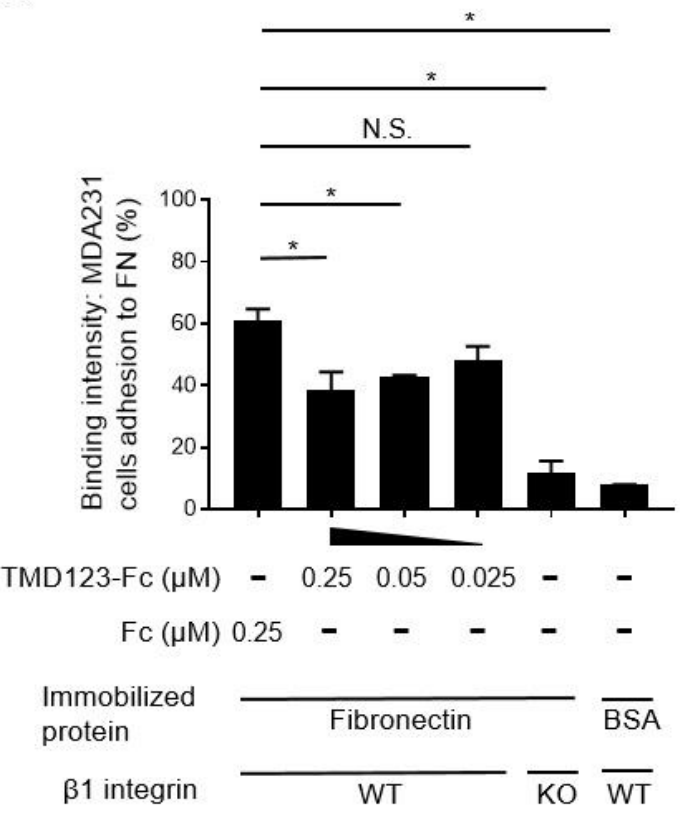

(b)

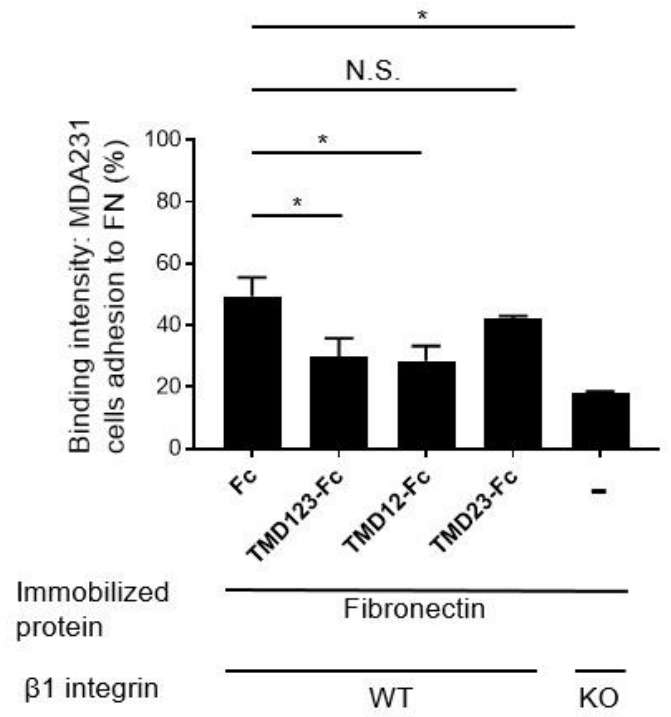

(c)

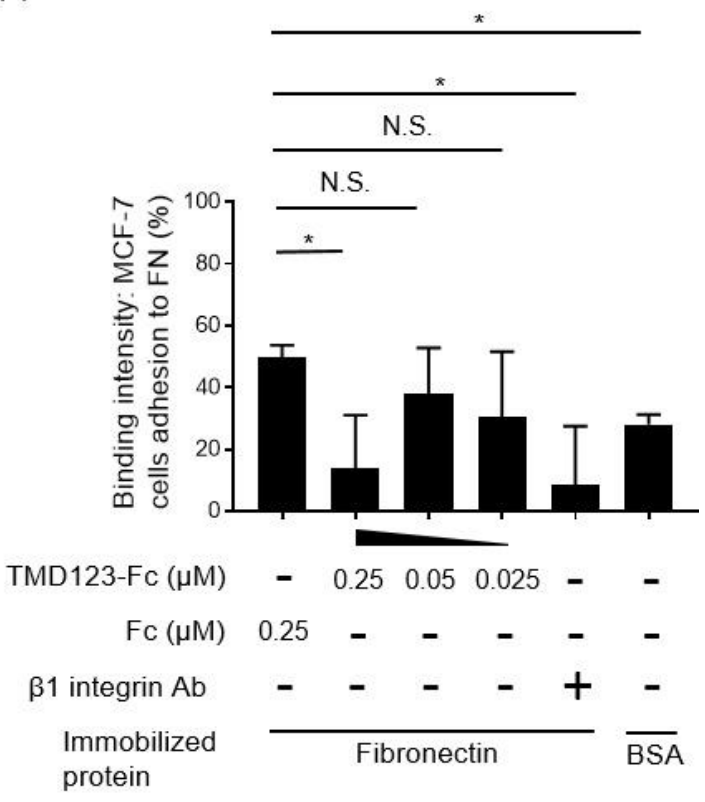

(d)

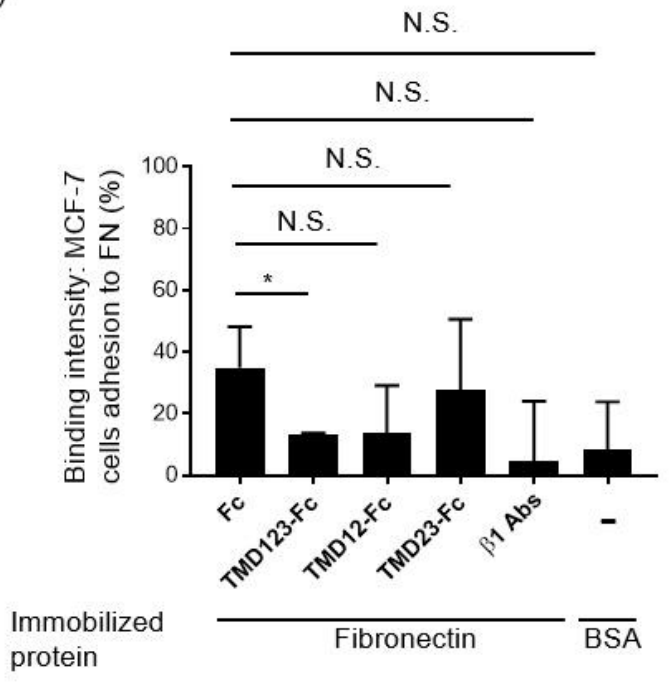

Figure 5. TMD123-Fc and TMD12-Fc inhibit the binding of MDA-MB-231 to fibronectin (FN). (a) TMD123-Fc inhibits the binding of fibronectin to MDA-MB-231 in a concentration-dependent manner. (b) Lectin-like domain of TM inhibits the $\beta 1$ integrin-dependent binding of MDA-MB-231 to fibronectin. (c) TMD123-Fc inhibits the binding of fibronectin to MCF-7 in a concentration-dependent manner. (d) The lectin-like domain of TM inhibits $\beta 1$ integrin-dependent binding of MCF-7 to fibronectin. V-wells were coated with $10 \mu \mathrm{g} / \mathrm{mL}$ fibronectin or $10 \mu \mathrm{g} / \mathrm{mL}$ BSA and then injected with calceinstained MDA-MB-231 and subjected to shear stress in the presence of $\mathrm{Mg}^{2+}$ and $\mathrm{Ca}^{2+}$. Experiments were performed in triplicate and repeated three times with similar results. Data are expressed as mean $\pm \mathrm{SD} .{ }^{*} p<0.05$ compared with control. N.S.: not significant; BSA: bovine serum albumin, Ab: antibody. 


\subsection{TM Inhibits the Integrin-Dependent Binding of MDA-MB-231 to Fibronectin in the Presence of $\mathrm{Ca}^{2+}$}

There is no $\mathrm{Ca}^{2+}$-binding site in the TM lectin-like domain [19]; however, the EGF-like extracellular domain of TM exerts its ability to activate protein $\mathrm{C}$ by binding $\mathrm{Ca}^{2+}[20,21]$. We confirmed the binding of fibronectin to human breast cancer-derived cell lines under two conditions (in the presence of $\mathrm{Mg}^{2+} / \mathrm{Ca}^{2+}$ or $\mathrm{Mg}^{2+}$ ) in order to examine whether the presence or absence of $\mathrm{Ca}^{2+}$ is important for TM binding to fibronectin. We found that binding of MDA-MB-231 to FN was inhibited in the presence of $\mathrm{Mg}^{2+}$ and $\mathrm{Ca}^{2+}(p<0.05)$ but not in the presence of $\mathrm{Mg}^{2+}$ (Figure 6).

(a)

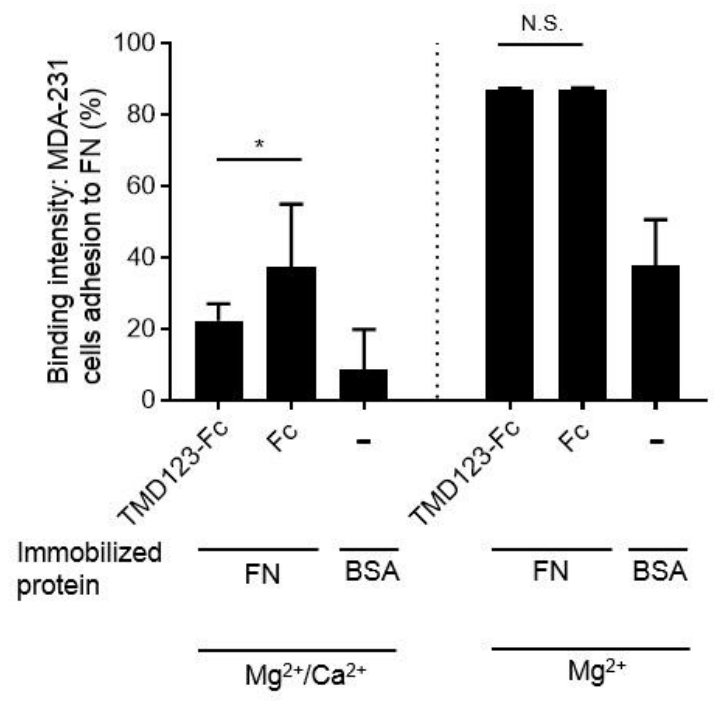

(b)

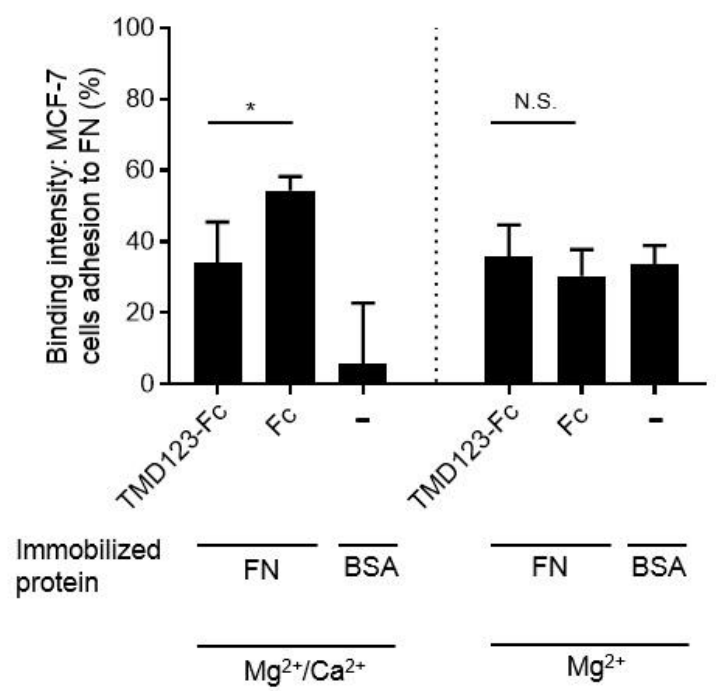

Figure 6. TMD123-Fc inhibits the binding of activated $\beta 1$ integrin to (a) MDA-231 or (b) MCF-7 cells and fibronectin (FN) under shear stress. The binding of TMD123-Fc to FN was analyzed by applying shear stress using V-well wells in the presence of $1 \mathrm{mM} \mathrm{Mg}^{2+}$ and $\mathrm{Ca}^{2+}$ or $1 \mathrm{mM} \mathrm{Mg}^{2+}$ alone. Experiments were performed in triplicate and repeated three times with similar results. Data are expressed as mean $\pm \mathrm{SD}$. ${ }^{*} p<0.05$. Compared with control. N.S.: not significant; BSA: bovine serum albumin. 


\subsection{Binding of MDA-231 Cells to Fibronectin Is Inhibited by TMD123-Fc}

We then examined whether TMD123-Fc could inhibit the binding of MDA-231 to fibronectin using flow cytometry analysis. Fibronectin or BSA was adsorbed onto the surface of fluorescent beads (green; diameter: $3 \mu \mathrm{m}$ ), and binding of MDA-231 to the beads was confirmed by flow cytometry in the presence of $1 \mathrm{mM} \mathrm{Mg}^{2+} / \mathrm{Ca}^{2+}, 1 \mathrm{mM} \mathrm{Mg}^{2+}$, and $2 \mathrm{mM}$ EDTA (Figure 7a). We found that fibronectin-coated beads bound MDA-231 $\beta 1$ integrin in the presence of $1 \mathrm{mM} \mathrm{Mg}^{2+} / \mathrm{Ca}^{2+}$ and $1 \mathrm{mM} \mathrm{Mg}^{2+}$ but not $2 \mathrm{mM}$ EDTA. Furthermore, the binding of fibronectin-coated beads to MDA-231 cells was inhibited by TMD123-Fc and TMD12-Fc (Figure 7b).

(a)

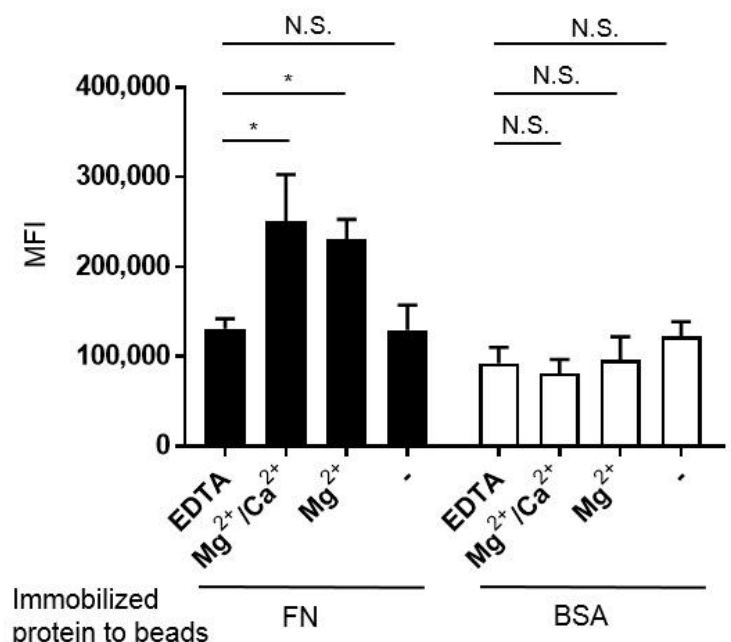

(b)

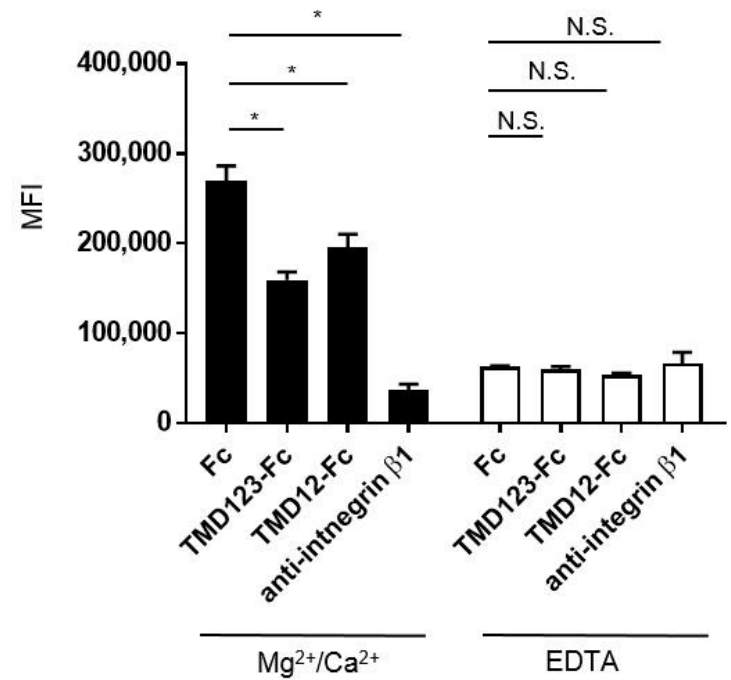

Figure 7. Binding of MDA-231 cells to fibronectin is inhibited by TMD123-Fc. (a) Binding of fibronectin- or BSA-coated fluorescent beads (green) to MDA-231 was analyzed by flow cytometry in the presence of $1 \mathrm{mM} \mathrm{Mg}^{2+} / \mathrm{Ca}^{2+}, 1 \mathrm{mM} \mathrm{Mg}^{2+}$, or $2 \mathrm{mM}$ EDTA. (b) Binding of fibronectin-coated fluorescent beads (green) to MDA-231 was inhibited by the $\beta 1$ integrin antibody or TMD123-Fc and TMD12-Fc in the presence of $1 \mathrm{mM} \mathrm{Mg}^{2+} / \mathrm{Ca}^{2+}$. Experiments were performed in triplicate and repeated three times with similar results. Data are expressed as the mean $\pm \mathrm{SD} .{ }^{*} p<0.05$. compared with control. N.S.: not significant; MFI: mean fluorescent intensity. 


\section{Discussion}

The integrin family of cell-adhesion receptors regulates a diverse range of cellular functions important for adhesion, migration, and metastasis of solid tumors. Integrin $\alpha 5 \beta 1$ recognizes and attaches to extracellular ligands containing RGD tripeptide motifs. Aberrant upregulation of integrin $\alpha 5 \beta 1$ has been implicated in many human malignancies and is closely associated with poor prognosis [22]. Therefore, studies on the molecular interactions between integrin $\beta 1$ and its ligands are essential for interpreting the biological functions and underlying mechanisms associated with $\beta 1$ integrin. The lectin-like domain of TM binds the ECM protein fibronectin; however, it remains unknown whether TM inhibits the adhesion of fibronectin to cancer cell integrins [5]. Here, we created recombinant proteins of the extracellular domain of TM and found that TMD123-Fc and TMD12-FC inhibited the $\beta 1$ integrin-dependent binding of human breast cancer-derived cell lines to fibronectin (Figures 5-7). Hence, TMD123-Fc administered into the bloodstream may inhibit fibronectin-mediated adhesion of breast cancer cells to the vascular endothelial cells and suppress cancer metastasis.

TM binds fibronectin (Figure 2) and is intimately involved in breast cancer invasion and metastasis [4]. TM is present in both the cytoplasm and on the cell surface of breast cancer cells, as well as in endothelial cells proximal to or in cancerous tissue. TM expression on the surface of breast cancer cells is significantly correlated with a high recurrence rate. Furthermore, TM expressed on the surface of tumor cells is involved in tumor invasion and angiogenesis via binding to the ECM [5]. Therefore, sufficient exogenously administered doses of TM might bind fibronectin on the vascular endothelium and inhibit the binding of tumor cell $\beta 1$ integrin to fibronectin.

As a way to increase the blood concentration of TMD123, which is certified for the treatment of septic disseminated intravascular coagulation (DIC), and as a way to enhance the drug's effect on rhsTM (also known as Recomodulin, which is an approved drug for DIC treatment), we focused on the Fc fusion protein, which has been used in several successful biopharmaceuticals in the past few decades. [23]. Based on the pharmacokinetic data obtained from healthy volunteers and patients with DIC, a once-daily intravenous infusion of $0.06 \mathrm{mg} / \mathrm{kg}$ rhsTM was recommended [24]. The half-life of rhsTM is approximately $20 \mathrm{~h}$, and more than $50 \%$ of the drug is excreted in urine. Our TMD123-Fc fusion protein not only showed the bioactivity of TM itself, but also displayed a long blood half-life conferred by the Fc region and is expected to maintain long-term effects owing to the slower renal clearance of larger sized molecules [25]. Therefore, TMD123-Fc may be a promising candidate for future therapeutic agents along with rhsTM.

We examined the inhibitory effect of TM on the binding of $\alpha 5 \beta 1$ integrin to fibronectin using human breast cancer-derived cell lines. Fibronectin also binds to other integrins [18]. MDA-MB-231 and MCF-7 do not harbor $\alpha 4 \beta 1$ integrin; however, neutrophils bind fibronectin via $\alpha 4 \beta 1$ integrin under shear stress [26]. Therefore, neutrophil $\alpha 4 \beta 1$ integrin might bind to fibronectin present on the surface of vascular endothelial cells, and TMD123Fc might inhibit this adhesion. Thus, in diseases such as sepsis where inhibition of excessive adhesion of neutrophils and vascular endothelial cells is important for the treatment, TMD123-Fc may be a promising candidate for a therapeutic agent. Indeed, exogenously administered rhsTM inhibits leukocyte and vascular endothelial cell adhesion both in vitro and in vivo [27,28]. Therefore, the inhibitory effect of TMD123-Fc with $\beta 1$ integrin and fibronectin could be applied as a therapeutic strategy for sepsis.

Approximately $1 \mathrm{mM}$ of $\mathrm{Ca}^{2+}$ and $\mathrm{Mg}^{2+}$ are present in the blood, and the presence of $\mathrm{Ca}^{2+}$ plays an important role in maintaining integrins in an inactive state. In our experiments, we activated integrins using shear stress in the presence of $1 \mathrm{mM}$ of $\mathrm{Ca}^{2+}$ and $\mathrm{Mg}^{2+}$ to mimic physiological blood conditions $[29,30]$. Notably, the removal of $\mathrm{Ca}^{2+}$ or the addition of $\mathrm{Mg}^{2+}$ significantly increases the ligand binding affinity of the integrins to ligands. This situation mimics the so-called excessive inflammation state. Our results showed that the absence of $\mathrm{Ca}^{2+}$ forced integrin activation and under these conditions, the binding of MDA-MB-231 and MCF-7 to fibronectin was not inhibited by TMD123-Fc 
administration (Figure 6). This suggests that once integrin is activated, TMD123-Fc is unable to inhibit the binding of MDA-MB-231 $\beta 1$ integrin to fibronectin. Therefore, it may be essential to administer TMD123-Fc in the early stages of inflammation, before integrins are activated. This is consistent with the clinical results that early administration of rhsTM is more effective in the treatment of sepsis [31].

There are several limitations to this study. First, $\beta 1$ integrin-KO animals usually die within a few hours after birth likely due to dehydration and loss of the required epidermal barrier [32]. The removal of $\beta 1$ integrin puts high stress on the cell; therefore, loss of $\beta 1$ integrin might adversely affect other integrin functions, such as proliferation and signal transduction, in addition to cell adhesion. Thus, adhesion of $\beta 1$ integrin-KO cells to fibronectin might be reduced beyond $\beta 1$-dependent binding (Figure $5 \mathrm{a}, \mathrm{b}$ ). Second, we found that TMD123-Fc inhibited the binding of human breast cancer-derived cell lines to fibronectin in vitro. However, we have not conducted in vivo experiments. A longer half-life may be necessary to prove the efficacy of TMD123-Fc in vivo. Third, in the current study, we did not include the rhsTM available drug for the anticoagulant therapy for sepsis-induced disseminated intravascular coagulation (DIC). We found that TMD123-Fc inhibits the binding of $\beta 1$ integrin of human breast cancer-derived cell lines to fibronectin. Therefore, it has also been suggested that the rhsTM inhibits the binding of $\beta 1$ integrin of human breast cancer-derived cell lines to fibronectin, but we have not demonstrated whether rhsTM has the same effect as TMD123-Fc in the current study. If future studies prove that rhsTM has similar effects, rhsTM could be rapidly introduced as a new therapeutic approach for the treatment of cancer. Finally, breast cancer is most commonly spread via lymphatics [33]. However, breast cancer migrates to distant organs by lymphogenous and hematogenous metastasis [34,35]. Because fibronectin is present in vascular endothelial cells, lymphatic vessels [36], and lymph nodes [37], TMD123-Fc might contribute to the inhibition of $\beta 1$ integrin binding to fibronectin at both vascular endothelial cells and lymph nodes.

\section{Conclusions}

We found that both TMD123-Fc and TMD12-Fc, which included the lectin-like domain of TM, inhibited the binding of shear stress-activated $\beta 1$ integrin from human breast cancerderived cell lines to fibronectin. These results could be applied to develop new therapeutic strategies for inhibiting the adhesion of breast cancer cells to vascular endothelial cells through $\beta 1$ integrin-mediated cell adhesion.

Supplementary Materials: The following are available online at https:/ /www.mdpi.com/2227-905 9/9/2/162/s1, Figure S1: Flow cytometry analysis of integrin expression on MCF-7 cells.

Author Contributions: Conceptualization, E.K. and M.S.; methodology, E.K.; software, E.K.; validation, E.K.; formal analysis, A.M.-I.; investigation, N.N., E.K.; resources, T.O., E.K.; data curation, E.K.; writing—original draft preparation, E.K.; writing—review and editing, E.K.; visualization, N.N.; supervision, Y.A., S.D., M.G.A., P.K.M., G.O., A.I., S.C., R.E., T.Y., H.I. and M.S.; project administration, M.S.; funding acquisition, E.K., M.S., A.G., E.J.P. All authors have read and agreed to the published version of the manuscript.

Funding: This work was supported by ISPS KAKENHI (Grants-in-Aid for Scientific Research) [grant numbers 19K07479, 2019], [grant numbers 18K08917, 2018], [grant numbers 9KK0224, 2019] and a research grant from Asahi Kasei Pharma.

Institutional Review Board Statement: Not applicable.

Informed Consent Statement: Not applicable.

Data Availability Statement: Please contact to the corresponding author for analyzed data.

Acknowledgments: We gratefully acknowledge Goichi Honda (Medical Affairs Department, Asahi Kasei Pharma Corporation) for his technical assistance. 
Conflicts of Interest: The authors declare no conflict of interest. The funders had no role in the design of the study; in the collection, analyses, or interpretation of data; in the writing of the manuscript, or in the decision to publish the results.

\section{References}

1. Esmon, C.T. The protein C pathway. Chest 2003, 124, 26S-32S. [CrossRef] [PubMed]

2. Okamoto, T.; Tanigami, H.; Suzuki, K.; Shimaoka, M. Thrombomodulin: A bifunctional modulator of inflammation and coagulation in sepsis. Crit. Care Res. Pr. 2012, 2012, 614545. [CrossRef] [PubMed]

3. Tezuka, Y.; Yonezawa, S.; Maruyama, I.; Matsushita, Y.; Shimizu, T.; Obama, H.; Sagara, M.; Shirao, K.; Kusano, C.; Natsugoe, S.; et al. Expression of thrombomodulin in esophageal squamous cell carcinoma and its relationship to lymph node metastasis. Cancer Res. 1995, 55, 4196-4200.

4. Kim, S.J.; Shiba, E.; Ishii, H.; Inoue, T.; Taguchi, T.; Tanji, Y.; Kimoto, Y.; Izukura, M.; Takai, S. Thrombomodulin is a new biological and prognostic marker for breast cancer: An immunohistochemical study. Anticancer Res. 1997, 17, 2319-2323. [PubMed]

5. Hsu, Y.Y.; Shi, G.Y.; Wang, K.C.; Ma, C.Y.; Cheng, T.L.; Wu, H.L. Thrombomodulin promotes focal adhesion kinase activation and contributes to angiogenesis by binding to fibronectin. Oncotarget 2016, 7, 68122-68139. [CrossRef] [PubMed]

6. Xiao, T.; Takagi, J.; Coller, B.S.; Wang, J.H.; Springer, T.A. Structural basis for allostery in integrins and binding to fibrinogenmimetic therapeutics. Nature 2004, 432, 59-67. [CrossRef] [PubMed]

7. Schaffner, F.; Ray, A.M.; Dontenwill, M. Integrin alpha5beta1, the fibronectin receptor, as a pertinent therapeutic target in solid tumors. Cancers 2013, 5, 27-47. [CrossRef] [PubMed]

8. Dos Santos, P.B.; Zanetti, J.S.; Ribeiro-Silva, A.; Beltrao, E.I. Beta 1 integrin predicts survival in breast cancer: A clinicopathological and immunohistochemical study. Diagn. Pathol. 2012, 7, 104. [CrossRef] [PubMed]

9. Yao, E.S.; Zhang, H.; Chen, Y.Y.; Lee, B.; Chew, K.; Moore, D.; Park, C. Increased beta1 integrin is associated with decreased survival in invasive breast cancer. Cancer Res. 2007, 67, 659-664. [CrossRef]

10. Dingemans, A.M.; van den Boogaart, V.; Vosse, B.A.; van Suylen, R.J.; Griffioen, A.W.; Thijssen, V.L. Integrin expression profiling identifies integrin alpha5 and beta1 as prognostic factors in early stage non-small cell lung cancer. Mol. Cancer 2010, 9, 152. [CrossRef]

11. White, D.E.; Kurpios, N.A.; Zuo, D.; Hassell, J.A.; Blaess, S.; Mueller, U.; Muller, W.J. Targeted disruption of beta1-integrin in a transgenic mouse model of human breast cancer reveals an essential role in mammary tumor induction. Cancer Cell 2004, 6, 159-170. [CrossRef]

12. Huck, L.; Pontier, S.M.; Zuo, D.M.; Muller, W.J. beta1-integrin is dispensable for the induction of ErbB2 mammary tumors but plays a critical role in the metastatic phase of tumor progression. Proc. Natl. Acad. Sci. USA 2010, 107, 15559-15564. [CrossRef] [PubMed]

13. Suzuki, K.; Kusumoto, H.; Deyashiki, Y.; Nishioka, J.; Maruyama, I.; Zushi, M.; Kawahara, S.; Honda, G.; Yamamoto, S.; Horiguchi, S. Structure and expression of human thrombomodulin, a thrombin receptor on endothelium acting as a cofactor for protein C activation. EMBO J. 1987, 6, 1891-1897. [CrossRef] [PubMed]

14. Kawamoto, E.; Okamoto, T.; Takagi, Y.; Honda, G.; Suzuki, K.; Imai, H.; Shimaoka, M. LFA-1 and Mac-1 integrins bind to the serine/threonine-rich domain of thrombomodulin. Biochem. Biophys. Res. Commun. 2016, 473, 1005-1012. [CrossRef] [PubMed]

15. Weetall, M.; Hugo, R.; Friedman, C.; Maida, S.; West, S.; Wattanasin, S.; Bouhel, R.; Weitz-Schmidt, G.; Lake, P. A homogeneous fluorometric assay for measuring cell adhesion to immobilized ligand using V-well microtiter plates. Anal. Biochem. 2001, 293, 277-287. [CrossRef]

16. Hou, S.; Isaji, T.; Hang, Q.; Im, S.; Fukuda, T.; Gu, J. Distinct effects of beta1 integrin on cell proliferation and cellular signaling in MDA-MB-231 breast cancer cells. Sci. Rep. 2016, 6, 18430. [CrossRef] [PubMed]

17. Danen, E.H.; Sonneveld, P.; Brakebusch, C.; Fassler, R.; Sonnenberg, A. The fibronectin-binding integrins alpha5beta1 and alphavbeta3 differentially modulate RhoA-GTP loading, organization of cell matrix adhesions, and fibronectin fibrillogenesis. J. Cell Biol. 2002, 159, 1071-1086. [CrossRef] [PubMed]

18. Humphries, J.D.; Byron, A.; Humphries, M.J. Integrin ligands at a glance. J. Cell Sci. 2006, 119, 3901-3903. [CrossRef]

19. Li, Y.H.; Kuo, C.H.; Shi, G.Y.; Wu, H.L. The role of thrombomodulin lectin-like domain in inflammation. J. Biomed. Sci. 2012, 19, 34. [CrossRef] [PubMed]

20. Light, D.R.; Glaser, C.B.; Betts, M.; Blasko, E.; Campbell, E.; Clarke, J.H.; McCaman, M.; McLean, K.; Nagashima, M.; Parkinson, J.F.; et al. The interaction of thrombomodulin with $\mathrm{Ca}^{2+}$. Eur. J. Biochem. 1999, 262, 522-533. [CrossRef] [PubMed]

21. Rezaie, A.R.; Esmon, C.T. The function of calcium in protein C activation by thrombin and the thrombin-thrombomodulin complex can be distinguished by mutational analysis of protein C derivatives. J. Biol. Chem. 1992, 267, 26104-26109. [CrossRef]

22. Gingras, M.C.; Roussel, E.; Bruner, J.M.; Branch, C.D.; Moser, R.P. Comparison of cell adhesion molecule expression between glioblastoma multiforme and autologous normal brain tissue. J. Neuroimmunol. 1995, 57, 143-153. [CrossRef]

23. Strohl, W.R. Current progress in innovative engineered antibodies. Protein Cell 2018, 9, 86-120. [CrossRef] [PubMed]

24. Moll, S.; Lindley, C.; Pescatore, S.; Morrison, D.; Tsuruta, K.; Mohri, M.; Serada, M.; Sata, M.; Shimizu, H.; Yamada, K.; et al. Phase I study of a novel recombinant human soluble thrombomodulin, ART-123. JTH 2004, 2, 1745-1751. [CrossRef] [PubMed]

25. Kontermann, R.E. Strategies for extended serum half-life of protein therapeutics. Curr. Opin. Biotechnol. 2011, 22, 868-876. [CrossRef] [PubMed] 
26. Reinhardt, P.H.; Elliott, J.F.; Kubes, P. Neutrophils can adhere via alpha4beta1-integrin under flow conditions. Blood 1997, 89, 3837-3846. [CrossRef] [PubMed]

27. Kawamoto, E.; Nago, N.; Okamoto, T.; Gaowa, A.; Masui-Ito, A.; Sakakura, Y.; Akama, Y.; Soe, Z.Y.; Prajuabjinda, O.; Darkwah, S.; et al. Anti-adhesive effects of human soluble thrombomodulin and its domains. Biochem. Biophys. Res. Commun. 2019, 511, 312-317. [CrossRef]

28. Iba, T.; Aihara, K.; Watanabe, S.; Yanagawa, Y.; Takemoto, M.; Yamada, A.; Yang, D. Recombinant thrombomodulin improves the visceral microcirculation by attenuating the leukocyte-endothelial interaction in a rat LPS model. Thromb. Res. 2013, 131, 295-299. [CrossRef]

29. Tzima, E.; del Pozo, M.A.; Shattil, S.J.; Chien, S.; Schwartz, M.A. Activation of integrins in endothelial cells by fluid shear stress mediates Rho-dependent cytoskeletal alignment. EMBO J. 2001, 20, 4639-4647. [CrossRef]

30. Davies, P.F.; Barbee, K.A.; Volin, M.V.; Robotewskyj, A.; Chen, J.; Joseph, L.; Griem, M.L.; Wernick, M.N.; Jacobs, E.; Polacek, D.C.; et al. Spatial relationships in early signaling events of flow-mediated endothelial mechanotransduction. Ann. Rev. Physiol. 1997, 59, 527-549. [CrossRef]

31. Banerjee, A.K.; Angulo, A.F.; Polak-Vogelzang, A.A.; Kershof, A.M. Naturally occurring genital mycoplasmosis in mice. Lab. Anim. 1985, 19, 275-276. [CrossRef] [PubMed]

32. Segre, J.A.; Bauer, C.; Fuchs, E. Klf4 is a transcription factor required for establishing the barrier function of the skin. Nat. Genet. 1999, 22, 356-360. [CrossRef] [PubMed]

33. Karaman, S.; Detmar, M. Mechanisms of lymphatic metastasis. J. Clin. Investig. 2014, 124, 922-928. [CrossRef] [PubMed]

34. Olsen, M.E. The incidence of renal artery stenosis and hypertension in patients on chronic intermittent haemodialysis. Dan. Med. Bull. 1983, 30, 343-345. [PubMed]

35. Schmidt-Kittler, O.; Ragg, T.; Daskalakis, A.; Granzow, M.; Ahr, A.; Blankenstein, T.J.; Kaufmann, M.; Diebold, J.; Arnholdt, H.; Muller, P.; et al. From latent disseminated cells to overt metastasis: Genetic analysis of systemic breast cancer progression. Proc. Natl. Acad. Sci. USA 2003, 100, 7737-7742. [CrossRef] [PubMed]

36. Murtomaki, A.; Uh, M.K.; Kitajewski, C.; Zhao, J.; Nagasaki, T.; Shawber, C.J.; Kitajewski, J. Notch signaling functions in lymphatic valve formation. Development 2014, 141, 2446-2451. [CrossRef]

37. Sobocinski, G.P.; Toy, K.; Bobrowski, W.F.; Shaw, S.; Anderson, A.O.; Kaldjian, E.P. Ultrastructural localization of extracellular matrix proteins of the lymph node cortex: Evidence supporting the reticular network as a pathway for lymphocyte migration. BMC Immunol. 2010, 11, 42. [CrossRef] [PubMed] 